\title{
Analysis Demand of Sipirok Weaving in Sangkumpal Bonang Market Padang Sidempuan
}

\author{
Mara Judan Rambey ${ }^{1}$, Sri Ulfa Sentosa ${ }^{2 *}$, Efrizal Syofyan ${ }^{3}$ \\ 1Universitas Negeri Padang, Padang, Indonesia $₫$ marajudan@gmail.com \\ 2Universitas Negeri Padang, Padang, Indonesia $₫$ sriulfasentosa66@gmail.com \\ 3Universitas Negeri Padang, Padang, Indonesia $\bowtie$ efrizalsyofyan@yahoo.com \\ ${ }^{*}$ Corresponding Author
}

\begin{abstract}
This study aims to analyze and determine the effect of Spirok weaving prices, Tarutung weaving prices, Balige weaving prices, income, tastes, number of dependents and expectations both partially and jointly on the demand for Spirok Weaving at Sangkumpal Bonang Market, Padang Sidempuan City. The number of samples is 112 people. The analytical method used is Ordinary Least Square (OLS). The results of the study concluded that the price of Sipirok, Tarutung, Balige weaving, income, tastes, number of dependents, and expectations significantly affected the demand for Spirok weaving in the Sangkumpal Bonang Market, Padang Sidempuan City. However, expectations do not have a significant effect on demand for Spirok weaving. Based on the results of these studies policies that can be suggested is the City Government of Padang Sidempuan together with the government of North Sumatra Province in order to always coordinate in order to encourage the increase in demand for Weaving Sipirok on the market.
\end{abstract}

Keyword: tenun sipirok, demand

\section{Introduction}

The city of Padangsidempuan is one of the districts that have the potential for cultural diversity and art that can be developed. This potential is spread in several sub-districts in the City of Padangsidempuan. This cultural and artistic diversity is managed by local communities to improve their welfare so that it can be a source of creative economy. One of the potentials that can be developed in the City of Padangsidempuan is embroidery and embroidery. The following is a table that shows the development of embroidery and embroidery industries in the City of Padangsidempuan in 2011 to 2015.

Based on data from the Department of Cooperative Industry and Trade, Padangsidempuan City in 2016, it can be seen that the number of embroidery / embroidery business units always increases every year even though the increase is only a little, but it can prove that embroidery / embroidery is a potential that can be developed in Padangsidempuan Kota. The increase in the number of business units is also accompanied by an increase in the number of workers that can be absorbed in this sector. Seeing the beauty of the Sipirok weaving motif, it is not surprising that people's demand is always increasing. Based on preliminary observations that the author did with several consumers of Sipirok weaving in the Sangkumpal Bonang market, Padangsidempuan, information was obtained that consumers were very fond of this weaving. This is because weaving is beautiful, made directly by hand, and the basic ingredients used are good materials. Although the price is far above the price of substitute goods, consumers still choose this weaving. This might be caused by the increase in people's income every year.

Based on data from the Biro Pusat Statistik of the City of Padangsidempuan, it can be seen that the income of the people of Padangsidempuan City has increased even though the increase is only around $10-11 \%$ per year. This increase in income will certainly increase the people's purchasing power so that it is expected to have an impact on the increase in demand for Weaving Sipirok. The price of Sipirok weaving substitutes is lower than the price of 
Sipirok weaving itself, but the higher price of Sipirok weaving is thought not to reduce consumers' interest in buying it.

Demand is the desire or desire of a person or group of people to be able to have a number of goods or services, accompanied by the ability to buy them at certain price levels and certain conditions. In other words, demand means a number of goods and services that can be purchased at certain times. According to Joesron (2003: 99) individual demand is the quantity of an item that a buyer wants to obtain at various price levels. Whereas according to Debertin (2012: 109) Demand is a number of goods or services which are economic goods that will be purchased by consumers at a certain price in a certain time or period.

Experts express their opinions about the factors that influence the high and low demand for goods and services. The following will describe the opinions of experts regarding the factors that influence demand. Samuelson and Nordhaus (2003: 62) explain that there are several factors that can influence the demand for goods and services are price, average income, population, prices of related goods, availability of related goods, and taste.

According to Kelana (2006: 29) the concept of demand explains that the demand for a product is influenced by the price of the product itself, the quality of the prices of other products that are related, consumer income, population, consumer expectations and others. Miller (2000: 73) suggests there are several factors that can influence the demand for goods and services, namely:

a. Price itself

If the price of a service is cheaper, then the demand for services increases. Vice versa, if the price of a service increases, the demand for services decreases.

b. Price of other related items

The price of other goods can also affect the demand for an item, but both types of services have relevance. The relationship of two types of goods can be substitute (substitute) and are complementary.

c. Per capita income level

The level of income per capita can reflect purchasing power. The higher the level of income, the stronger the purchasing power, so that the demand for a service increases.

d. Taste or Habit

A person's interest in goods and services will cause high demand for goods and services.

e. Total population

The more population, the more demand for goods and services.

f. Estimated prices in the future

If we estimate that the price of a service will go up, it is better to buy the service now, so that it encourages people to buy more now to save spending in the future.

g. Income distribution

h. If income distribution is poor, it means that purchasing power is generally weak, so that demand for a service decreases.

Besides that, Kelena (2006: 30) suggests that several factors that influence demand include:

a. Changes in the price of the product itself

If there is a change in the price of the product itself, there will be a change in the number of products requested. This can be modeled as a movement along the demand curve.

b. Income

Consumer income affects the ability of consumers to buy products. Changes in income will affect the amount of goods that consumers can buy at various price levels. The increase in income will increase the purchasing power of consumers, so that with the same price level consumers will be able to buy more products. If this is demonstrated, it will be seen as a shift in the entire right demand curve.

In this case the consumer consumption pattern is to increase the number of products requested if the income increases. Such products are referred to as normal products, 
namely goods whose demand will increase if the consumer's income increases. And vice versa if the consumer's income decreases, the demand for the item will also decrease. Consumers can also show different consumption patterns.

Increasing consumer income will actually reduce demand for a product (shifting the left supply curve). Such products in the eyes of consumers are called inferior products. The inferior product refers to goods whose number of requests will decrease if the consumer's income increases. This happens because with the increase in purchasing power because of the increase in income, consumers assume that the product is of low quality, no longer in line with the current level of income.

c. Price of Other Related Products

Changes in the prices of other related products generally shift the demand curve for a product. As an example of the increase in the price of chicken meat, it would make some consumers switch to buying beef because the price of chicken meat is now relatively more expensive. Because many consumers substitute chicken meat for beef, the total demand for beef at each price level is higher. As a result, the increase in the price of chicken meat raises the demand for beef. The relationship is mutually substituted.

Relations between two products can also complement each other. Complementary products are products that must be used at the same time, because their functions are complementary. The increase in the price of complementary products from a product will reduce the demand for these products.

d. Product design and quality

High-quality products with more attractive designs will usually attract more consumers than products with the same price but the quality and design are less attractive. The quality of a product or service offered by the company is reflected in the product itself: such as excellent service, collateral damage or spare parts, or it can also be formed by promotional and advertising activities.

e. Consumer Expectation

The influence of consumer expectations on product demand, is very visible for durable products. For example, if consumers estimate that car prices will increase next year, then this year's car will increase in anticipation of the increase in car prices that year. Thus, buying a car is currently considered a substitute for buying a car next year. Consumer expectations here also include consumer expectations about the availability and possibility of product substitution in the future. If consumers estimate that $\mathrm{U}$ product substitution will emerge next year with more attractive design and quality, current consumer demand for $\mathrm{U}$ products will decline.

f. Total Population

The demand for a product is also influenced by changes in the number of distribution and composition of the population. For example, the demand for food products has continued to increase from year to year other than due to an increase in income, also due to the increase in population. In communities with increasingly old population structures, there tends to be an increase in demand for health products and services. While for younger structured communities (in their 30s) for example, it turns out that increasing demand increases demand for baby equipment, services for play groups and kindergarten education.

Previous research related to the author's research is the research of Rodriques (2014) who found that the demand for textiles in Bulgaria was influenced by prices, substitute prices, income, tastes, expectations and marketing strategies. Clark (2015) concludes that prices, substitute prices, quality of goods, income, expectations and advertisements influence buyer demand for clothing in Scotland. Hillary (2016) concludes that prices, prices of substitute goods, promotion costs, income, and consumer tastes influence buyers' demand for clothing 
in Hungary. William (2016) concludes that prices, substitution prices, motives, advertising costs, income, and consumer tastes influence buyer demand for fashion in Yugoslavia.

\section{Methods}

The population in this study were all consumers or buyers who bought Sipirok Weaving at the Sangkumpal Bonang Market in Kota Padangsidempuan. Malhotra (2003) provides guidance on the sample size taken can be determined by multiplying the number of variables by 7 , or $7 \times$ the number of variables. Thus because the number of variables to be observed amounts to 7 , the number of samples is $7 \times 8=56$. Therefore the number of samples used as respondents in this study amounts to $56 \times 2=112$ people.

The sampling technique used in this study was through accidental sampling techniques. Accidental sampling technique is a sampling technique based on coincidence, that is, who is accidentally encountered and can be sampled, if viewed by the person who happened to be found is the consumer or buyer who bought Sipirok Weaving in Sangkumpal Bonang Market, Padangsidempuan, so that it is suitable as a data source.

As stated in the theory study, the Sipirok weaving demand equation in this study influenced the prices of Sipirok weaving, Tarutung weaving prices, Balige weaving prices, consumer income, consumer tastes, family members and consumer expectations. Where the form of functional equations is as follows:

$$
Y=f\left(X_{1}, X_{2}, X_{3}, X_{4}, X_{5}, X_{6}, X_{7}\right)
$$

To simplify the above equation, then the equation is transformed into a logarithmic equation in order to obtain its elasticity, therefore the following equation is obtained;

$$
\begin{aligned}
Y= & \beta_{0}+\beta_{1} X_{1}+\beta_{2} \log X_{2}+\beta_{3} \log X_{3}+\beta_{4} \log X_{4}+\beta_{5} \log X_{5}+\beta_{6} \log X_{6} \\
& +\beta_{7} \log X_{7}+\mu
\end{aligned}
$$

Where $\mathrm{Y}$ is the demand for Sipirok weaving, $\mathrm{X} 1$ is the price of Sipirok weaving, $\mathrm{X} 2$ is the price of Tarutung weaving, $\mathrm{X} 3$ is the price of Balige weaving, $\mathrm{X} 4$ is the consumer's income, $\mathrm{X} 5$ is the consumer's taste, $\mathrm{X} 6$ is the number of family members, $\mathrm{X} 7$ is consumer expectations.

\section{Results and Discussion}
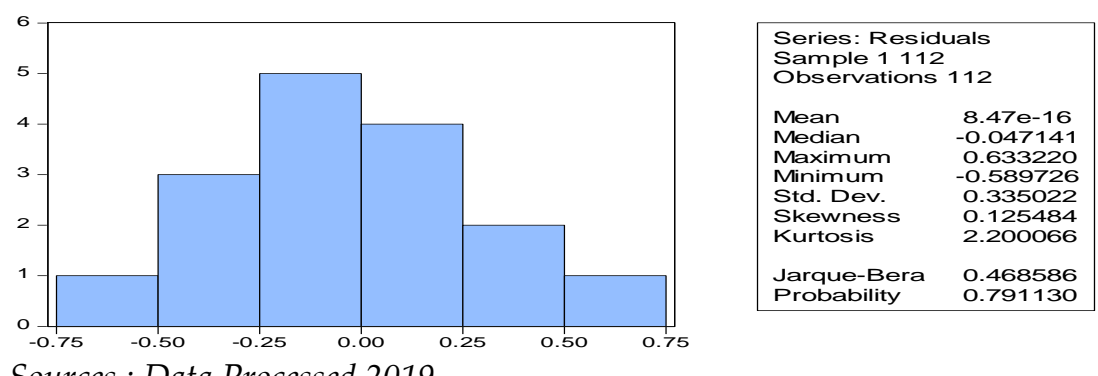

Sources : Data Processed,2019

Figure 1 Normality test

The results of the normality test of the data in this study can be seen in Figure 1. From the results of the normality test with the Jarque Bera (JB) method above, it can be seen that the Probability value of JB (0.791130)>0.05. Therefore the JB value> 0.05 , it can be said that the variable data distribution in this study has a normal distribution. Data that is normally distributed means that the data is centered on the data center, namely the average, median and mode. 
Table 1 Multicollinearity test

Variance Inflation Factors

Date: 04/04/18 Time: 01:11

Sample: 1112

Included observations: 112

\begin{tabular}{cccc}
\hline \hline Variable & $\begin{array}{c}\text { Coefficient } \\
\text { Variance }\end{array}$ & $\begin{array}{c}\text { Uncentered } \\
\text { VIF }\end{array}$ & $\begin{array}{c}\text { Centered } \\
\text { VIF }\end{array}$ \\
\hline \hline C & 35.05367 & 3525.786 & NA \\
X1 & 0.104788 & 1646.448 & 1.130584 \\
X2 & 0.072390 & 1132.530 & 1.142431 \\
X3 & 0.097382 & 1524.735 & 1.139142 \\
LOG(X4) & 0.037261 & 623.5510 & 1.232231 \\
X5 & 0.008196 & 21.80201 & 1.044938 \\
X6 & 0.014189 & 6.625941 & 1.119493 \\
X7 & 0.052421 & 3.813211 & 1.055442 \\
\hline \hline
\end{tabular}

Sources : Data Processed,2019

From multicollinearity testing in Table 1 it can be seen that the Centered VIF values of all variables $(X 1, X 2, X 3, X 4$. X5, X6, and $X 7)<5$. Therefore it can be concluded that there is no strong correlation between variables free.

Table 2 Heteroskedasticity test

Heteroskedasticity Test: Glejser

\begin{tabular}{llll}
\hline \hline F-statistic & 0.803490 & Prob. F(7,104) & 0.5862 \\
Obs ${ }^{*}$ R-squared & 5.746314 & Prob. Chi-Square(7) & 0.5697 \\
Scaled explained SS & 7.369630 & Prob. Chi-Square(7) & 0.3914 \\
\hline
\end{tabular}

Sources : Data Processed,2019

From the results of heteroscedasticity test in Table 2 (attachment) with the Glejser method, it can be seen that the Probability value F (0.5862) of all variables $>0.05$. Because the F probability value is $<0.05$, it can be said that there is no heteroscedasticity problem in this study.

Table 3 Estimation Result

Dependent Variable: Y

Method: Least Squares

Date: 04/04/18 Time: 01:09

Sample: 1112

Included observations: 112

\begin{tabular}{crrrr}
\hline \hline Variable & Coefficient & Std. Error & t-Statistic & Prob. \\
\hline \hline C & 9.583777 & 5.920614 & 1.618713 & 0.1085 \\
X1 & -0.652163 & 0.142477 & -4.577331 & 0.0000 \\
X2 & 0.495167 & 0.134737 & 3.675051 & 0.0007 \\
X3 & 0.355475 & 0.147635 & 2.407798 & 0.0208 \\
LOG(X4) & 0.527757 & 0.164951 & 3.199477 & 0.0027 \\
X5 & 0.949490 & 0.153042 & 6.204095 & 0.0000
\end{tabular}


Table Cont...

\begin{tabular}{lllll}
\multicolumn{1}{c}{ X6 } & 0.495167 & 0.134737 & 3.675051 & 0.0007 \\
\multicolumn{1}{c}{ X7 } & 0.170140 & 0.094081 & 1.808439 & 0.0779 \\
\hline \hline R-squared & 0.429103 & Mean dependent var & 2.419643 \\
Adjusted R-squared & 0.436246 & S.D. dependent var & 1.036613 \\
S.E. of regression & 1.055232 & Akaike info criterion & 3.014147 \\
Sum squared resid & 115.8054 & Schwarz criterion & 3.208325 \\
Log likelihood & 160.7922 & Hannan-Quinn criter. & 3.092931 \\
F-statistic & 14.45353 & Durbin-Watson stat & 1.808530 \\
Prob(F-statistic) & 0.000000 & & \\
\hline \hline
\end{tabular}

Sources : Data Processed,2019

Equation 1 is the estimation of the effect of Spirok Weaving prices, Tarutung weaving prices, Balige weaving prices, income, tastes, number of dependents and expectations of demand for Spirok Weaving at Sangkumpal Bonang Market, Kota Padang Sidempuan. From the estimation results that have been done, we can get the Teni Spirok demand equation model as follows:

$$
\begin{aligned}
Y & =9.583777-0.652163 X_{1}+0.495167 X_{2}+0.355475 X_{3} \\
& +0.527757 \log X_{4}+0.949490 X_{5}+0.495167 X_{6}+0.170140 X_{7}
\end{aligned}
$$

Based on the results of the analysis above, it can be seen that if the Spirok Weaving price, Tarutung weaving price, Balige weaving price, income, taste, number of dependents and expectations are zero then the value of Spirok Weaving price in Sangkumpal Bonang Market, Kota Padangsidempuan is 9.583777 percent. The value of R-squared from the demand equation for weaving spikes is 0.429103 . This shows the contribution of Spirok Weaving price variables, Tarutung weaving prices, Balige weaving prices, income, tastes, number of dependents and expectations of demand for Spirok Weaving in Sangkumpal Bonang Market, Kota Padangsidempuan is 42.91 percent while the remaining 57.09 percent is affected by other variables not included in the demand equation for Spirok Weaving at Sangkumpal Bonang Market, Kota Padangsidempuan.

The first alternative hypothesis in this study proved to be accepted. Thus, the price of Sipirok weaving has a significant effect on the demand for Spirok Weaving in the Sangkumpal Bonang Market, Kota Padangsidempuan. There is a significant influence between the price of Sipirok weaving and the demand for Sipirok weaving indicating that the demand for Sipirok weaving is influenced by the price of Sipirok weaving. This condition indicates that if the price of Sipirok weaving increases, the demand for Sipirok weaving will decrease. This situation is caused by prices being a burden or cost for consumers. When prices increase, the burden for consumers will also increase, so consumers will reduce the demand for Sipirok weaving. Conversely, if prices decline, consumer demand for Sipirok weaving will increase because the burden or cost of buying Sipirok weaving drops.

The second alternative hypothesis in this study proved to be accepted. Thus, the price of Sipirok weaving has a significant effect on the demand for Spirok Weaving in the Sangkumpal Bonang Market, Kota Padangsidempuan. The existence of a significant influence between the price of Tarutung weaving on the demand for Sipirok weaving indicates that the demand for Sipirok weaving is influenced by the price of Tarutung weaving. Tarutung weaving and Sipirok weaving in this study are substitute goods. When the price of Tarutung weaving increases, the demand for Tarutung weaving will decrease because consumers experience a decrease in purchasing power towards Tarutung weaving. Then consumers will divert their requests to Sipirok weaving. Conversely, when the price of Tarutung weaving 
decreases, the demand for Tarutung weaving will increase because consumers experience a strengthening of purchasing power. Therefore, consumers will divert their request to Tarutung weaving so that the demand for Sipirok weaving decreases.

The third alternative hypothesis in this study proved to be accepted. Thus, the price of Sipirok weaving has a significant effect on the demand for Spirok Weaving in the Sangkumpal Bonang Market, Kota Padangsidempuan. There is a significant influence between Balige weaving prices on Sipirok weaving demand indicating that the demand for Sipirok weaving is influenced by the price of Balige weaving. Weaving Balige and Sipirok weaving in this study are also substitute goods. When the price of Balige weaving increases, the demand for Balige weaving will also decrease because consumers experience a decline in purchasing power towards Balige weaving. Then consumers will divert their requests to Sipirok weaving. Conversely, when the price of Balige weaving falls, the demand for Tarutung weaving will increase because consumers experience a strengthening in purchasing power. Therefore, consumers will divert their request to Balige weaving so that the demand for Sipirok weaving decreases.

The fourth alternative hypothesis in this study proved to be accepted. Thus, income has a significant effect on the demand for Spirok Weaving at Sangkumpal Bonang Market, Kota Padangsidempuan. The existence of a significant influence between income on demand for Sipirok weaving indicates that the demand for Sipirok weaving is influenced by income. This condition is because when income increases, the purchasing power of consumers will increase. Increasing purchasing power, consumers will have more money so that this will have an impact on rising consumer demand for Sipirok weaving. Conversely, when income decreases, the purchasing power of consumers will also go down because of the less money they have. The purchasing power that has decreased will result in a decline in consumer demand for Sipirok weaving.

The fifth alternative hypothesis in this study proved to be accepted. Thus, the tastes have a significant effect on the demand of Spirok Weaving at Sangkumpal Bonang Market, Kota Padangsidempuan. There is a significant influence between appetite for Sipirok weaving requests indicating that the demand for Sipirok weaving is influenced by taste. This condition is due to the higher a person's taste, the higher one's interest in goods and services. This increased interest will encourage someone to increase their demand. Whereas if someone tastes down then their interest in goods and services will also decrease. This situation will cause the demand to go down.

The sixth alternative hypothesis in this study proved to be accepted. Thus, the number of dependents has a significant effect on the demand for Spirok Weaving in the Sangkumpal Bonang Market, Kota Padangsidempuan. There is a significant influence between the number of dependents on Sipirok weaving requests indicating that the demand for Sipirok weaving is influenced by the number of dependents. This condition is because when the number of family members increases, population demand for goods and services will also increase. This increase in the number of family members will have an impact on the increasing demand for Sipirok weaving. Conversely, when the number of family members decreases, the population's demand for goods and services also falls, one of which is the demand for Sipirok weaving. This decrease in demand for Sipirok weaving will force the price of Sipirok weaving to drop in the market.

The seventh alternative hypothesis in this study proved to be accepted. Thus, the expectation does not have a significant effect on the demand for Spirok weaving at the Sangkumpal Bonang Market, Kota Padangsidempuan. The absence of a significant influence between expectations for Sipirok weaving demand indicates that the demand for Sipirok weaving is not affected by expectations. This condition is because Sipirok weaving is not a basic necessity. This means that it is not a necessity that is very much needed but he is only as fashion and appearance at certain events. When an item and service is a basic need, 
expectations of future price increases will drive current demand. Because, these items are needed in life. So even though the price of Sipirok weaving is expected to rise in the future, consumers will not increase their demand at this time.

\section{Conclusions}

The results of the study concluded that (1) The price of Sipirok weaving had a significant negative effect on the demand for Spirok weaving at the Sangkumpal Bonang Market in Kota Padangsidempuan. With the meaning of the word, the increase or increase in the price of Sipirok weaving will encourage a decrease in demand for weaving Spirok. (2) The price of Sipirok weaving has a significant negative effect on the demand for Spirok weaving at Sangkumpal Bonang Market, Kota Padangsidempuan. With the meaning of the word, the increase or increase in the price of Sipirok weaving will encourage a decrease in demand for weaving Spirok. (3) The price of Balige weaving has a positive and significant effect on the demand for Spirok weaving in the Sangkumpal Bonang Market, Kota Padangsidempuan. If the price of Balige weaving increases, the demand for Spirok weaving will also be boosted. (4) Revenue affects demand for Spikrok weaving in Sangkumpal Bonang Market, Kota Padangsidempuan significantly and positively. This means that if the income increases, the demand for Spirok weaving at the Sangkumpal Bonang Market in the City of Padang Sidempuan will also increase. (5) Taste also affects the demand for Spirok weaving in the Sangkumpal Bonang Market in Kota Padangsidempuan significantly and positively. This means that the higher the taste of consumers towards Sipirok weaving in the Sangkumpal Bonang Market, Kota Padangsidempuan, the demand will also increase. (6) The number of dependents is significant and positively influences the demand for Spirok weaving in the Sangkumpal Bonang Market, Kota Padangsidempuan. This means that the greater the number of dependents, the higher the demand for consumption, among others, is Spirok weaving in the Sangkumpal Bonang Market, Kota Padangsidempuan. (7) Furthermore, expectations have no significant effect on the demand for Spirok weaving at the Sangkumpal Bonang Market in Kota Padangsidempuan. Although the price of Sipirok weaving is expected to rise in the future it will not encourage consumers to increase their current demand.

Based on the results of these studies the policies that can be suggested are the City Government of Kota Padangsidempuan together with the government of North Sumatra Province to always coordinate in creating the stability of Sipirok Weaving prices on the market. This price stability is very much needed by consumers and producers of Weaving Sipirok so that consumers and producers are not harmed by the price of Sipirok Weaving which is not clearly on the market. This policy can be done by means of the interaction between the supply and demand of the Sipirok Weaving. If the increase in weaving price is caused by a decrease in supply, the government must be able to increase supply.

\section{References}

Clark, Stevenson. (2015). Demand and Clothes Children. International Journal of Economic and Bussines. Vol 3. No. 2. 122-141.

Debertin, David L. (2012). Agricultural Production Economics. Macmillan Publishing Company, New York.

Hillary, Dion. (2016) Clothes and Determinat Fluctuations. International Journal of Economic and Finance. Vol. 5. No. 1.75-89.

Joesron, Tati S dan Fathorrozi. (2003). Teori Ekonomi Mikro. Jakarta: Salemba Empat.

Kelana, Said. (2006). Teori Ekonomi Mikro. Jakarta: PT Raja Grafindo Persada.

Nicholson, Walter. (2011). Microeconomics. Florida: Harcourt Brace \& Company.

Silvester, Johansen. (2014). Demand and Determinant. International Journal of Economics and Aplication. Vol. 4 No. 2. 77-102. 
William, Robinson. (2016). Fashion and It's Demand. International Journal of Economics, Bussines and Accounting. Vol 2. No. 1. 88-102. 